\title{
Recent Developments regarding Human Immunodeficiency Virus Infection and Stroke
}

\author{
Souvik Sen ${ }^{a}$ Alejandro A. Rabinstein ${ }^{b}$ Mitchell S.V. Elkind ${ }^{c}$ William J. Powers ${ }^{d}$ \\ a University of South Carolina, Columbia, S.C., 'b Mayo Clinic, Rochester, Minn., 'Columbia University, New York, N.Y., \\ and ${ }^{d}$ University of North Carolina, Chapel Hill, N.C., USA
}

\section{Key Words}

Antiretroviral therapy $\cdot$ Human immunodeficiency virus • Non-nucleoside reverse transcriptase inhibitors $\cdot$ Protease inhibitor · Stroke

\begin{abstract}
Human immunodeficiency virus (HIV) infection is strongly associated with ischemic stroke in the young. Data obtained from the Nationwide Inpatient Sample in the United States show an increase in the number of stroke hospitalizations in the HIV-infected population despite an overall decrease in the number of stroke hospitalizations. Few data exist, however, that address the mechanism of HIV-associated stroke. Recent studies have demonstrated that HIV may infect the endothelium and alter cerebrovascular functions. Whether the proposed mechanism alters the stroke risk is undetermined. Epidemiological studies suggest that HIV-related stroke is associated with a risk factor profile that differs from the HIV-negative young stroke population in that HIV-associated strokes are less likely to have hypertension, diabetes, hyperlipidemia and smoking as risk factors. A large population-based study, moreover, suggests an association between antiretroviral therapy and increased cardio- and cere-
\end{abstract}

brovascular risks. Specific antiretroviral agents such as protease inhibitors and non-nucleoside reverse transcriptase inhibitors have been implicated in the metabolic syndrome, accelerated atherosclerosis and an increased risk for ischemic stroke. In addition to discussing these developments, this paper also discusses the implications of recent data for stroke prevention in HIV-infected patients.

Copyright $\odot 2012$ S. Karger AG, Basel

\section{Introduction}

Stroke is a leading cause of adult disability in the United States [1]. Available data suggest that human immunodeficiency virus (HIV) infection is strongly associated with ischemic stroke in the young (15-44 years of age) [2]. Moreover, the number of stroke hospitalizations in the HIV population in the United States has increased by $61 \%$ from 1997 to 2006 despite an overall decrease in the number of stroke hospitalizations [3]. Few data exist, however, that address the mechanism of HIV-associated stroke. Recent studies have demonstrated that HIV may infect the endothelium and alter cerebrovascular functions, but whether this proposed mechanism increases stroke risk

\section{KARGER}

Fax +4161306 1234 E-Mail karger@karger.ch www.karger.com
(C) 2012 S. Karger AG, Basel

$1015-9770 / 12 / 0333-0209 \$ 38.00 / 0$

Accessible online at:

www.karger.com/ced
Prof. Souvik Sen, MD, MS, MPH, FAHA

University of South Carolina School of Medicine

8 Medical Park Drive, Suite 420

Columbia, SC 29203 (USA)

Tel. +1 803545 6073,E-Mail souvik.sen@uscmed.sc.edu 
is uncertain. Epidemiological studies suggest that HIVassociated stroke is associated with a risk factor profile that differs from the HIV-negative young stroke population in that HIV-associated strokes are less likely to have hypertension, diabetes, hyperlipidemia and smoking as risk factors. Antiretroviral therapy may also be associated with an increased risk of cerebrovascular events. Specific antiretroviral agents such as protease inhibitors (PI) and non-nucleoside reverse transcriptase inhibitors (NNRTI) have been implicated in the metabolic syndrome, accelerated atherosclerosis and an increased risk for ischemic stroke. In addition to discussing these developments, this paper also discusses the implications for stroke prevention in HIV-infected patients.

\section{Epidemiology}

Epidemiological data on cerebrovascular disease in HIV-infected patients may differ depending on the type of the population (i.e. industrialized countries vs. SubSaharan Africa) and the date of the study period [i.e. before vs. after highly active antiretroviral therapy (HAART) implementation]. Consequently, the question of whether HIV infection is an independent risk factor for stroke is challenging. Necropsy studies of HIV-infected subjects have shown the prevalence of cerebral infarction ranging between 6 and 34\% [4]. These pathological findings have often been considered asymptomatic [4]. In fact, the rates of stroke-like presentations in different cohorts of patients with HIV infection have not exceeded 5\%, supporting the subclinical nature of some of the lesions identified at necropsy $[5,6]$. Many of these necropsy and clinical series date back to the pre-HAART era and include a majority of patients with advanced acquired immunodeficiency syndrome (AIDS). Yet, most contemporary clinical series consistently show that strokes continue to occur at young ages $(<50$ years) in HIV-infected patients [3, 7-9]. No population-based studies have been conducted to determine if the incidence of stroke is increased by HIV infection. Retrospective case-control studies, however, indicate that HIV infection and particularly the diagnosis of AIDS appear to be associated with an increased risk of stroke in industrialized countries [5, 10, 11]. More limited information is available from African cohorts $[12,13]$. At this time, whether HIV infection is a risk factor for stroke in African patients remains unclear. A summary of data from industrialized countries and from African cohorts is displayed in table 1 .

\section{Causes and Mechanisms}

Clinical series predating the broad use of HAART consistently reported that cerebral infarction was more frequent in patients with advanced immunosuppression, and cerebral infarction was often associated with opportunistic infections and tumors [14]. Marantic endocarditis, prothrombotic states and complications of intravenous drug abuse were also commonly implicated. A specific type of cerebral vasculopathy characterized by arterial ectasia and aneurysm formation was recognized first in HIV-infected children and then in young adults as a cause of cerebral infarction and brain hemorrhage [15]. Pathologically proven cases of vasculitis (i.e. inflammatory changes in the walls of small cerebral arteries) ascribed to HIV infection per se have been rarely described and their significance remains unclear. Evidence that HAART, particularly regimens containing PIs, produces metabolic changes that can accelerate atherosclerosis [16] and increase the risk of myocardial infarction [17] motivated the conduction of more recent studies evaluating the mechanisms of ischemia in HIVinfected patients.

In South Africa, during the years 2000-2006, only $12 \%$ of $67 \mathrm{HIV}$-infected patients treated for a first stroke had received antiretroviral therapy and at the time of their stroke, $46 \%$ of these patients had CD 4 counts $<200$ cells $/ \mathrm{mm}^{3}$ [7]. Ischemic strokes largely predominated (96\%) and most patients (91\%) were younger than 46 years. Recent or intercurrent opportunistic infections were noted in 25 cases (37\%) and were deemed the cause of stroke in 18 patients (28\%). The most common infection was tuberculosis (15\%). Extracranial or intracranial (aneurysmal or non-aneurysmal) vasculopathy without documented risk factors for atherosclerosis (defined by the investigators as 'HIV-associated vasculopathy') was observed in 13 cases (20\%). Anti-cardiolipin antibodies were present in 12 (19\%) patients and cardioembolism in 9 (14\%) patients. Traditional vascular risk factors were uncommon in these HIV-infected patients with stroke [7]. Among 82 patients with stroke [77 with ischemic infarction and 5 with intracerebral hemorrhage (ICH)] at a large inner-city hospital in the United States [8], 61\% of patients (mean age 42 years) had been treated with HAART, but most patients were severely immunosuppressed at the time of the stroke (mean CD4 count was 113 cells $/ \mathrm{mm}^{3}$ and $85 \%$ had counts $<200$ cells $/ \mathrm{mm}^{3}$ ). The mechanism of ischemic stroke was classified as large artery atherosclerosis in $12 \%$, cardiac embolism in $18 \%$, small artery occlusion in $18 \%$, other determined cause in 
Table 1. HIV infection and risk of stroke

\begin{tabular}{|c|c|c|c|c|}
\hline First author & Population & $\begin{array}{l}\text { Methods/ } \\
\text { study period }\end{array}$ & Rate & Comments \\
\hline \multicolumn{5}{|c|}{ Studies in HIV-infected patients } \\
\hline Engstrom [6] (1989) & 1,600 patients with AIDS & $\begin{array}{l}\text { case series } \\
1982-1987\end{array}$ & $12(0.75 \%)$ & probable under-recognition \\
\hline Connor [4] (2000) & 183 necropsies of HIV cases & $\begin{array}{l}\text { necropsy } \\
\text { series }\end{array}$ & $10(5.5 \%)$ & $\begin{array}{l}\text { excluded cases with CNS } \\
\text { opportunistic infections }\end{array}$ \\
\hline Evers [5] (2003) & 772 patients with HIV & $\begin{array}{l}\text { cohort study } \\
1993-2001\end{array}$ & 15 IS/TIA (1.9\%) & $\begin{array}{l}\text { incidence of IS/TIA } 216 \\
\text { per } 100,000 \text { patients/year }\end{array}$ \\
\hline Corral [9] (2009) & $\begin{array}{l}\text { 2,012 patients with HIV } \\
\text { treated with HAART }\end{array}$ & $\begin{array}{l}\text { case series } \\
1996-2008\end{array}$ & $\begin{array}{l}27 \text { IS/TIA in } 25 \\
\text { patients }(1.2 \%)\end{array}$ & $\begin{array}{l}\text { incidence of first-ever IS/TIA } 189 \\
\text { per } 100,000 \text { patients/year }\end{array}$ \\
\hline \multicolumn{5}{|l|}{ Studies in stroke patients } \\
\hline Qureshi [11] (1997) & $\begin{array}{l}236 \text { young ( } 19-44 \text { years) } \\
\text { patients with stroke }\end{array}$ & $\begin{array}{l}\text { case-control } \\
1990-1994\end{array}$ & $25(10.6 \%)$ & IS OR 3.4 with HIV infection \\
\hline Hoffmann [12] (2000) & $\begin{array}{l}1,298 \text { South African patients } \\
\text { with stroke ( } 151 \text { blacks) }\end{array}$ & case-control & $\begin{array}{l}25 \text { of } 1,298(1.9 \%) ; \\
24 \text { of } 151 \text { blacks }(15.9 \%)\end{array}$ & $\begin{array}{l}\text { no increase in the incidence rate } \\
\text { of stroke compared with patients } \\
\text { without HIV infection }\end{array}$ \\
\hline Cole [2] (2004) & $\begin{array}{l}556 \text { cases of stroke } \\
\text { ( } 385 \text { IS, } 171 \text { ICH) }\end{array}$ & $\begin{array}{l}\text { case-control } \\
1988-1991\end{array}$ & $12(2.2 \%)$ & $\begin{array}{l}\text { incidence of IS and ICH in AIDS } \\
\text { patients } 0.2 \% \text { per year for both } \\
\text { ARR } 9.1 \text { for cerebral infarction } \\
\text { and } 12.7 \text { for ICH }\end{array}$ \\
\hline Patel [13] (2005) & $\begin{array}{l}293 \text { young ( } 15-44 \text { years) black } \\
\text { African patients with stroke }\end{array}$ & $\begin{array}{l}\text { case-control } \\
1987-2002\end{array}$ & $56(19.1 \%)$ & OR for IS 2.3 with HIV infection \\
\hline Tipping [7] (2007) & $\begin{array}{l}\text { 1,087 African patients with } \\
\text { stroke }\end{array}$ & $\begin{array}{l}\text { case series } \\
2000-2006\end{array}$ & $67(6.2 \%)$ & $\begin{array}{l}91 \% \text { of HIV-infected patients with } \\
\text { stroke were }<46 \text { years }\end{array}$ \\
\hline
\end{tabular}

Each study has at least 100 patients included. Rate = Rate of stroke or HIV infection, respectively. CNS = Central nervous system; IS = ischemic stroke; $\mathrm{OR}=$ odds ratio; $\mathrm{ARR}=$ adjusted relative risk ratio.

$23 \%$ and cryptogenic in $29 \%$. Confirmed or probable vasculitis was considered the cause of the stroke in 10 (13\%) patients and stroke was attributed to hypercoagulability in $7(9 \%)$ patients [8].

In summary, in contemporary clinical series, strokes tend to occur in young patients with uncontrolled HIV infection and more severe immunosuppression. These strokes may occur because of opportunisitic infections associated with HIV and AIDS as there is evidence in non-HIV populations that chronic infections are nonspecifically associated with stroke risk [18]. Atypical causes remain common and many events are classified as cryptogenic. The mechanisms implicated in HIV-related strokes are listed in table 2.

\section{Cerebrovascular Function in HIV-Infected Patients}

Studies of peripheral arterial function in HIV-infected patients have shown consistent reductions in flow-mediated arterial dilation indicating deficient generation of endothelium-dependent nitric oxide (NO). There appears to be a contribution from the infection as well as from the antiretroviral therapy [19]. The role played by $\mathrm{NO}$ in the regulation of cerebral blood flow (CBF) is under investigation. There is evidence $\mathrm{NO}$ is involved in vasodilatory CBF responses to hypercapnia, hypoxia and hypotension [20]. Inhibition of NO resulted in a greater reduction in $\mathrm{CBF}$ when systemic mean arterial pressure (MAP) was reduced from 100 to $70 \mathrm{~mm} \mathrm{Hg}$ [20]. Impaired compensatory responses by the cerebral vasculature to reductions in systemic blood pressure could increase the 
Table 2. Causes and mechanisms of stroke in HIV-infected patients

Direct effect of HIV

HIV-related vasculitis/vasculopathy cardiac mechanisms

\section{Cardiac mechanisms}

Cardiac embolism

Endocarditis

Infection

No infection

Cardiomyopathy (low LVEF) ${ }^{\mathrm{a}}$

With dilated left ventricle

Without dilated left ventricle

Valvular disease (particularly myxoid valvular degeneration)

Opportunistic infectious/neoplastic mechanisms

Opportunistic vasculitis/vasculopathy

Opportunistic infections (with or without meningitis)

Tuberculosis

Cytomegalovirus

Varicella-zoster virus

Syphilis

Toxoplasmosis

Cryptococcosis

Other opportunistic infections

Opportunistic tumors

Lymphoma

Prothrombotic mechanisms

Coagulation diathesis

Protein S deficiency

Antiphospholipid antibodies

Others

Drug-related mechanisms

Intravenous drug abuse

Cocaine

Heroin

Cardiovascular risk-associated mechanisms

Atherosclerosis (may be accelerated with HAART)

Dyslipidemia, insulin resistance ${ }^{\mathrm{b}}$

Endothelial dysfunction?

LVEF = Left ventricular ejection fraction.

${ }^{a}$ May be associated with mural thrombi.

b These metabolic disturbances have been documented with regimens containing PI and nucleoside analog reverse transcriptase inhibitors.

risk of stroke, especially in the presence of underlying arterial stenosis.

Under normal conditions, changes in systemic blood pressure over a wide range have little effect on CBF due to autoregulation, which is mediated by changes in arteriolar diameter. When blood pressure increases, the small arter- ies and arterioles constrict to maintain $\mathrm{CBF}$ at a normal level. Similarly, when cerebral perfusion pressure decreases, vasodilation of the small arteries or arterioles prevents $\mathrm{CBF}$ from falling. This mechanism is effective at maintaining CBF in normal human subjects until the capacity for blood vessels to dilate in response to reduced blood pressure is exhausted [21]. Within the limits of autoregulation, a $10 \%$ decrease in MAP produces only a slight $(2-7 \%)$ decrease in regional CBF [22]. When blood pressure falls below the lower autoregulatory limit and the maximum compensatory vasodilatory capacity of the cerebral circulation has been exceeded, CBF will decline markedly with further reductions in cerebral perfusion pressure. Oxygen extraction, normally $30-40 \%$, will progressively increase as CBF falls to maintain oxygen metabolism [23]. When the increase in oxygen extraction is maximal and is no longer adequate to supply the energy needs of the brain, further reductions in blood pressure disrupt normal cellular metabolism and may produce ischemic cell death [24].

Stenosis of the large cerebral arteries produces no hemodynamic effect until a critical reduction of $60-70 \%$ in vessel lumen occurs. At this point, the arterial blood pressure distal to the stenosis may be reduced [25]. Even with this or greater degrees of stenosis, however, distal intravascular pressure is variable and may even remain normal with stenosis exceeding $90 \%$ because the hemodynamic effect of carotid artery stenosis depends not only on the degree of stenosis but also on the adequacy of the collateral circulation [25]. Thus, even when systemic arterial pressure is normal or high, the smaller arteries and arterioles distal to a large artery stenosis may be dilated in response to the reduced local perfusion pressure. Any reduction in systemic blood pressure, even within the normal range, could further reduce the pressure beyond the stenosis enough to precipitate cerebral infarction. This phenomenon has been most clearly described in patients with internal carotid artery occlusion who have ipsilateral hemispheric increases in oxygen extraction, indicating severe reductions in distal intra-arterial pressure. These patients are at high risk for stroke, but the stroke rarely occurs in the setting of any significant systemic hypotension [26].

Given the extensive literature about peripheral arterial function in HIV-infected patients, there are surprisingly few data on cerebrovascular function. Decreased common carotid artery distensibility or increased wall stiffness has been measured in HIV patients [27]. Decreased distensibility is present in early atherosclerosis; however, since the elastic properties of the common carotid artery are not important in the regulation of $\mathrm{CBF}$, 
the significance of this finding is uncertain. Among 31 HIV-infected subjects (aged 23-59 years) with no stenotic or occlusive large artery lesions and 10 similarly aged controls, middle cerebral artery blood flow velocity at baseline and after treatment with $1 \mathrm{~g}$ of acetazolamide (ACZ) was reduced in the HIV-infected subjects [28]. ACZ is a carbonic anhydrase inhibitor that dilates distal intracranial vessels by an unknown mechanism and is most commonly used in patients with large artery stenosis or occlusion to assess the hemodynamic effect on the distal circulation. A failure to normally increase CBF in response to $\mathrm{ACZ}$ is inferred to mean autoregulatory vasodilation has taken place in response to reduced downstream perfusion pressure, conferring an increased risk of stroke [29]. While abnormal ACZ reactivity in the absence of large artery disease presumably reflects smaller artery vasodilatory dysfunction, the clinical significance as far as conferring risk of stroke is unknown.

Direct (rather than inferred) determination of autoregulatory function requires measurement of the effects of changes in MAP on CBF. The autoregulatory index (AI) reflects the effectiveness of autoregulation: $\mathrm{AI}=-$ change in $\mathrm{CBF}(\%) /$ change in MAP (\%).

The negative sign means that $\mathrm{CBF}$ decreases as MAP decreases. An AI of 0 would be perfect. In animal experiments, the normal AI varies by species, hypotensive agent and CBF method. AI is usually slightly negative, -0.06 to -0.29 [22]. There are no published normal data for humans.

In a pilot study of autoregulation in HIV-infected patients, CBF was measured by MRI with continuous arterial spin labeling in 5 subjects, 4 of whom were on antiretroviral treatment at baseline and after blood pressure reduction [unpubl. data, 2009]. Nicardipine infusion reduced MAP from $92 \pm 11$ to $83 \pm 11 \mathrm{~mm} \mathrm{Hg}$. There was a statistically significant change in CBF from $51 \pm 8$ to $46 \pm 8 \mathrm{ml} / 100 \mathrm{~g} / \mathrm{min}(\mathrm{p}=0.03)$. AI was $-1.2 \pm 1.42$. These pilot data suggest that autoregulatory vasodilation in response to reduced MAP may be impaired in patients with HIV, but studies including more patients and normal controls are needed.

Although there is extensive literature about peripheral arterial function in HIV-infected patients, there are few data on cerebrovascular function, which has potential importance to the mechanism and prevention of stroke in these patients. The very small amount of data available suggests cerebrovascular function is impaired in HIV-infected patients. The relative contributions of infection and antiretroviral therapy as well as the relevance to HIVrelated stroke are still to be determined.

\section{HAART and Stroke}

As discussed above, patients with HIV infection may suffer a stroke due to a wide spectrum of mechanisms and etiologies. HAART has been effective in reducing opportunistic infections in AIDS patients and has transformed HIV infection from a progressively fatal condition to a manageable chronic disease. Paradoxically, recent studies have found associations between HAART and vascular events, particularly myocardial infarction. In particular, there has been concern about a possible risk of accelerated atherosclerosis associated with HAART, particularly with PIs, which may also cause dyslipidemia and insulin resistance [30]. The specific association between HAART and stroke, however, is yet to be ascertained in a population-based study.

A retrospective review compared the incidence rate of various events, including stroke, among 506 AIDS patients treated with HAART to the incidence rate among patients treated before the HAART era [31]. During the study period, 6 of the 506 patients presented with cerebrovascular events. There were 1 subarachnoid hemorrhage, $1 \mathrm{ICH}$ with cerebral toxoplasmosis and 4 ischemic events (3 instances of large vessel disease and 1 instance of lacunar infarction) [31]. The incidence rates of ischemic stroke and ICH were more than twofold higher than rates reported before the HAART era in different parts of the world. A more recent retrospective review of ischemic strokes and transient ischemic attacks (TIA) occurring in a cohort of HIV-infected patients treated with HAART from 1996 to 2008, compared with controls drawn from an unselected group in the same cohort, found an independent association of stroke with HAART, a prior diagnosis of AIDS and history of high alcohol consumption. The study concluded that stroke incidence is high in patients with HIV infection treated with HAART [9]. Refer to table 3 for a summary of studies examining HAART and the risk of stroke.

While these retrospective studies reveal higher stroke rates in HIV-infected subjects in the HAART era, they do not establish a specific association between HAART and stroke. In a large prospective cohort study, the incidence of cardio- and cerebrovascular events increased with longer exposure to HAART after excluding those patients associated with other concomitant central nervous system diseases [32]. In another study, however, the global incidence of cardio- or cerebrovascular disease was shown to be decreased in the short term in AIDS patients after treatment with HAART, excluding cases of cerebrovascular disease associated with drug dependence and 
Table 3. HAART and the risk of stroke in HIV-infected patients

\begin{tabular}{|c|c|c|c|c|}
\hline First author & Population & Methods/study period & Effect size & Significance \\
\hline $\begin{array}{l}\text { D:A:D Study } \\
\text { Group [32] } \\
(2004)\end{array}$ & $\begin{array}{l}23,648 \text { subjects in Europe, USA and } \\
\text { Australia on HAART therapy for } \\
\text { approximately } 6 \text { years }\end{array}$ & $\begin{array}{l}\text { prospective cohorts } \\
1999-2002\end{array}$ & $\begin{array}{l}\text { RR for cardiac and } \\
\text { cerebrovascular events was } \\
1.26 / \text { year of HAART exposure }\end{array}$ & $\begin{array}{l}\mathrm{p}<0.0001 \text { Poisson } \\
\text { regression model }\end{array}$ \\
\hline $\begin{array}{l}\text { Subsai } \\
{[31](2006)}\end{array}$ & $\begin{array}{l}\text { pre-HAART }=155 \text {; HAART }=506 \text {, } \\
\text { in Thailand followed over } 2 \text { years } \\
\text { after initiation of HAART }\end{array}$ & $\begin{array}{l}\text { retrospective } \\
\text { case-cohort study } \\
2002-2004\end{array}$ & $\begin{array}{l}\text { IS and HS incidence; } \\
\text { pre-HAART: } 0.2 \% / \text { year; } \\
\text { HAART: } 0.4 \% / \text { year }\end{array}$ & $\begin{array}{l}\mathrm{p}=0.001 \text { Poisson } \\
\text { regression analysis }\end{array}$ \\
\hline $\begin{array}{l}\text { Bozzette } \\
{[58](2008)}\end{array}$ & $\begin{array}{l}41,213 \text { persons in the USA followed } \\
\text { for } 4 \text { years }\end{array}$ & $\begin{array}{l}\text { retrospective cohort } \\
1993-2008\end{array}$ & $\begin{array}{l}\text { reduction in HR for death, } \\
\text { cardiovascular events and } \\
\text { stroke by } 0.18 \text { (PI or NNRTI) } \\
\text { and over } 72 \text { months }\end{array}$ & $\begin{array}{l}95 \% \mathrm{CI} \\
0.15-0.23\end{array}$ \\
\hline $\begin{array}{l}\text { Corral } \\
{[9](2009)}\end{array}$ & $\begin{array}{l}2,012 \text { HIV subjects in Spain initiated } \\
\text { on HAART followed for a mean of } \\
6.6 \text { years; stroke/TIA cases }=25 ; \\
\text { control }=100\end{array}$ & $\begin{array}{l}\text { case-control study } \\
1996-2008\end{array}$ & $\begin{array}{l}\text { fewer months under HAART } \\
\text { was associated with } \\
\text { cerebrovascular events } \\
\text { (OR 0.97) }\end{array}$ & $\begin{array}{l}95 \% \mathrm{CI} \\
0.96-0.99\end{array}$ \\
\hline
\end{tabular}

$\mathrm{D}: \mathrm{A}: \mathrm{D}=$ Data collection on adverse events of anti-HIV drugs; $\mathrm{RR}=$ relative risk; $\mathrm{IS}=$ ischemic stroke; $\mathrm{HR}=\mathrm{hazard}$ ratio; $\mathrm{CI}=$ confidence interval; $\mathrm{OR}=$ odds ratio.

HIV-related infections [33]. In neither study was the impact of HAART on the incidence of ischemic stroke analyzed as a specific endpoint. Moreover, mechanisms of stroke were not specified and while HAART may reduce stroke caused by AIDS-associated disorders, in the long term, HAART may increase atherothrombotic strokes. Nevertheless, an increase in the frequency of atherothrombotic strokes in patients receiving HAART could not be demonstrated in a recent clinical series [8]. Based on these large epidemiological studies, no conclusion can be drawn as to whether HAART is specifically associated with stroke. The evidence thus far indicates a positive association between PI [17] and NNRTI [34], but not NNRTI [17] and cardiovascular disease. Whether such a differential association of HAART subtype exists with stroke also remains to be determined. If determined, the finding could have a major impact on stroke prevention in HIV-infected subjects.

One mechanism by which HAART may increase the risk of a vascular event, including stroke, is through accelerated atherosclerosis by inducing dyslipidemia and insulin resistance [16]. Other proposed mechanisms include HAART-induced inflammation, as evidenced by an increase in serum markers such as high-sensitivity C-reactive protein and interleukin-6, contributing to accelerated atherosclerosis [34]. There is also evidence HAART may reduce the effects of endothelial dysfunction induced by
HIV. Despite the beneficial effect of HAART, the overall effect on atherosclerosis may be deleterious and translate into a clinical risk of stroke and cardiovascular disease. Data from a case-control study demonstrate a higher than expected prevalence of premature carotid lesions detected by ultrasound in PI-treated versus PI-naive patients [35]. These findings were confirmed in HIV-infected patients on combination antiretroviral therapy by comparing the risk of subclinical atherosclerosis between patients at low and high coronary risk. Combination antiretroviral therapy was found to be a strong, independent predictor for the development of subclinical atherosclerosis in HIV-infected patients, regardless of known major cardiovascular risk factors and atherogenic metabolic abnormalities induced by this therapy. The majority of these patients were treated with PI [16].

One plausible argument is HIV-associated strokes during the HAART era occur because HAART extends the life expectancy of HIV-infected individuals, therefore, increasing their risk of stroke. In a recent study, the median age for HIV-associated stroke was the 5th decade, which is much lower than in the non-HIV-infected population [3]. This finding suggests, during the HAART era, that HIV-associated stroke may not be due solely to longer exposure to vascular risk factors and/or HAART. 


\section{Implications for Prevention of Stroke in HIV-Infected Patients}

With the lack of clear specific mechanistic targets, prevention of stroke in HIV-infected patients is similar to prevention of stroke in patients without HIV, albeit with a few twists. As in patients without HIV, the first two steps of stroke prevention are the assessment of stroke risk and the treatment of conventional risk factors. The treatment of HIV can also be regarded as an important part of stroke prevention in these patients, as there is evidence that HIV may contribute to vasculopathy. Treatment using HAART, however, may produce or worsen vascular disease risk factors. Moreover, HAART requires particular choices of medications, monitoring of side effects and adjustments of medications, particularly in patients with a history of stroke or other vascular diseases.

\section{Assessment of Risk}

Current approaches to primary prevention of vascular disease and secondary stroke prevention rely on estimates of the absolute vascular risk [36]. The American Heart Association primary prevention guidelines state that those with $\geq 10 \%$ risk of myocardial infarction or coronary death over 10 years should be considered for aspirin therapy [37]. The NCEP (National Cholesterol Education Program) Adult Treatment Panel III guidelines state patients who have already experienced a cardiac event should be considered candidates for maximal medical therapy for secondary prevention, including statins with a goal LDL $<100 \mathrm{mg} / \mathrm{dl}$, or for those at 'very high risk' $<70 \mathrm{mg} / \mathrm{dl}$ [38]. Included in the group of coronary risk equivalents are those with diabetes mellitus; patients with multiple risk factors whose composite risk score, based on the Framingham risk profile [39], puts them at a $\geq 20 \% 10$-year risk, and patients with occlusive atherosclerotic disease, including those patients with symptomatic carotid artery disease. Although the NCEP guidelines do not explicitly address whether stroke patients should be included among risk equivalents, emerging data suggest that patients with stroke are at the same high level of risk as those with coronary artery disease, and that stroke patients could reasonably be included among coronary risk equivalents [40]. Given the clinical and public health importance of cerebrovascular disease, moreover, one can reasonably speak not only of 'coronary risk equivalents' but of 'stroke and coronary risk equivalents' [41]. Inclusion of stroke among the relevant and important outcomes is likely to be especially important among minority groups who are at an increased risk of stroke relative to coronary events [42]. Moreover, these minority groups are also likely to be overrepresented among those with HIV.

The first step in preventing a first stroke among HIVinfected patients, then, is to determine their absolute risk of stroke and other vascular events, using the Framingham risk score or a similar risk assessment tool, which can be easily found online [43]. While there is limited evidence that these risk scoring systems may underestimate the burden of cardiovascular disease in patients with HIV [44], at present, no other scoring systems have been generally accepted for this subgroup of patients [43, 45 . Those at high risk ( $>20 \%$ over 10 years) should then be considered for early treatment with antiretroviral therapy, as well as vascular preventive strategies [46].

\section{Treatment of Conventional Risk Factors}

Although there is limited evidence for secondary prevention of stroke in HIV patients, current guidelines regarding the use of antiplatelet agents, statins and blood pressure-lowering therapies should be used in patients with HIV as they are used in patients without HIV for the management of traditional risk factors in these patients [47]. For patients who have already experienced an ischemic stroke, identifying the specific proximate cause of the stroke is essential, when possible, to treat these patients accordingly. For instance, patients with atrial fibrillation will require anticoagulation and those with symptomatic carotid stenosis $>70 \%$ most likely should undergo a carotid endarterectomy [48]. In the absence of these conditions, most patients with ischemic stroke will be candidates for antiplatelet therapy. Statin therapy and blood pressure-lowering therapy will also be indicated to control hypercholesterolemia and hypertension $[46,47]$.

Smoking is particularly prevalent among patients with HIV (47-71\% of patients) and abstinence should be aggressively pursued [49]. Pharmacological therapy, including varenicline, bupropion, nortriptyline, clonidine and nicotine replacement, may all be tried. Currently, obesity is also common among patients with HIV, which represents a change from the early days of this disease, when many patients presented with wasting and cachexia. Obesity is present in $>40 \%$ of women and $>60 \%$ of men with HIV [50]. Therefore, encouraging weight loss and aerobic exercise $30-60 \mathrm{~min}$ at least 5 times weekly is important; in addition, patients should see a nutritionist when weight loss is not achieved [43].

There is also evidence that HIV, even before initiation of HAART, is associated with dyslipidemia [51]. 
Lipid abnormalities may occur in HIV-infected patients, including decreased total cholesterol, decreased LDL, decreased HDL, increased triglycerides and increased proatherogenic small LDL particles. Several of these abnormalities potentially have proatherogenic effects that may also increase stroke risk. These effects should be managed, as indicated, with statins, fibrates or other agents.

\section{Treatment of HIV}

There is some evidence that HIV, even before initiation of HAART, was associated with an increased risk of stroke. Some large trials, moreover, provide evidence that aggressive viral suppression with HAART reduces the risk of fatal or non-fatal cardiovascular events (annual event rate $1.3 \%$ among those randomized to drug conservation vs. $0.8 \%$ among those randomized to aggressive viral suppression, $p=0.05$ ) [52]. For these reasons, treatment of HIV may be considered part of a strategy to reduce stroke risk, among other benefits. Current guidelines for the management of patients with HIV, therefore, include the presence of a high risk of vascular disease as a reason to initiate HAART, even among patients with CD 4 counts $>350 / \mathrm{mm}^{3}$ [45]. This guideline represents, in fact, one of the few official recommendations to use antiretroviral therapies to reduce the risk of vascular disease [53]. These vascular protective benefits of treatment, however, must be weighed against the risk of medication-induced metabolic abnormalities, including diabetes, which themselves can contribute to stroke risk.

\section{Adjusting HAART in the Setting of Vascular Disease,}

High Risk or Risk Factors

The awareness of metabolic complications of specific antiretroviral agents has led to the search for agents with better metabolic profiles. The primary guide to choose the appropriate antiretroviral agent should, in general, be the efficacy of the agent in the individual patient against the virus. Treatment of metabolic complications can then be managed as needed. There are data to support the use of statins and fibrates for the management of lipid levels among patients on HAART, rather than to change to a different antiretroviral [54]. When choosing initial therapy, however, there are advantages to avoiding or choosing specific antiretroviral and lipid-lowering agents. For instance, the PI atazanavir appears less likely to be associated with hyperlipidemia and insulin resistance and should be considered, when possible, in patients who are known to be at high cardiovascular risk [55]. Abacavir has also been associated with increased cardiovascular risk and should be avoided among patients who are already at high risk [56]. PIs also downregulate the cytochrome $\mathrm{P}_{450}$ enzymes (e.g. CYP3A4) involved in the metabolism of specific statins; thus they may increase the levels of those statins. Therefore, use of pravastatin, atorvastatin or rosuvastatin in preference to lovastatin or simvastatin is reasonable [51].

Insulin resistance and diabetes mellitus are also common side effects of HAART. Insulin resistance may occur in up to $90 \%$ of patients treated with PIs, and $1-11 \%$ may develop overt diabetes mellitus over the course of 5 years. Diabetes may be accompanied by dyslipidemia, hypertension and visceral fat accumulation (i.e. the metabolic syndrome). As previously mentioned, atazanavir is less likely to cause these side effects. Patients on HAART should be advised to follow a diet that contains 50-60\% carbohydrates, $10-20 \%$ protein, $<30 \%$ fat, $<100 \mathrm{mg}$ cholesterol and $<10 \%$ of total calories from saturated fat. In addition, these patients should be advised to exercise. When needed, medications to control diabetes, including metformin, rosiglitazone, pioglitazone or insulin, should be prescribed to maintain a goal $\mathrm{Hb}_{\mathrm{AlC}}<6.5 \%$ and a fasting blood sugar of 73-110 mg/dl [43].

Lipodystrophy also occurs frequently among patients on HAART and may take the form of either fat accumulation, which occurs in $17-67 \%$ of patients on HAART, or lipoatrophy, which is found in $20-75 \%$ of patients on HAART. Fat accumulation is associated with the use of PIs, but may also be seen in HIV disease alone and with efavirenz, an NNRTI. Lipoatrophy is associated with NNRTI. The management of these conditions may include changing from a PI to an NNRTI, following a lowfat diet, exercise, use of testosterone and use of growth hormone. There is evidence the growth hormone-releasing hormone analog tesamorelin administered daily for 26 weeks decreases visceral fat by $18 \%$ and improves lipid profiles. These effects may be useful in HIV-infected patients who have treatment-associated central fat accumulation [57]. Further studies are needed to confirm these benefits and to demonstrate benefits in clinical outcomes among such patients.

\section{Conclusion}

Infection with HIV may contribute to an increased risk of stroke. The mechanism by which HIV infection leads to this increase in stroke risk needs to be determined. HAART, specifically PI and NNRTI, have been 
associated with metabolic syndrome and accelerated atherosclerosis, which may compound an increased stroke risk. These findings need to be confirmed in populationbased studies. Once confirmed, these findings could have widespread implications for stroke prevention in HIVinfected subjects.

\section{Acknowledgment}

Roxanne Poole, BS, provided editorial assistance.

\section{Disclosure Statement}

The authors have no conflicts of interest to declare.

\section{References}

1 Centers for Disease Control and Prevention (CDC): Prevalence of disabilities and associated health conditions among adults United States, 1999. MMWR Morb Mortal Wkly Rep 2001;50:120-125.

- 2 Cole JW, Pinto AN, Hebel JR, Buchholz DW, Earley CJ, Johnson CJ, Macko RF, Price TR, Sloan MA, Stern BJ, Wityk RJ, Wozniak MA, Kittner SJ: Acquired immunodeficiency syndrome and the risk of stroke. Stroke 2004;35: 51-56.

-3 Ovbiagele B, Nath A: Increasing incidence of ischemic stroke in patients with HIV infection. Neurology 2011;76:444-450.

-4 Connor MD, Lammie GA, Bell JE, Warlow CP, Simmonds P, Brettle RD: Cerebral infarction in adult AIDS patients: observations from the Edinburgh HIV Autopsy Cohort. Stroke 2000;31:2117-2126.

$\checkmark 5$ Evers S, Nabavi D, Rahmann A, Heese C, Reichelt D, Husstedt IW: Ischaemic cerebrovascular events in HIV infection: a cohort study. Cerebrovasc Dis 2003;15:199-205.

- 6 Engstrom JW, Lowenstein DH, Bredesen DE: Cerebral infarctions and transient neurologic deficits associated with acquired immunodeficiency syndrome. Am J Med 1989;86: 528-532.

7 Tipping B, de Villiers L, Wainwright H, Candy S, Bryer A: Stroke in patients with human immunodeficiency virus infection. J Neurol Neurosurg Psychiatry 2007;78:1320-1324.

$\checkmark 8$ Ortiz G, Koch S, Romano JG, Forteza AM, Rabinstein AA: Mechanisms of ischemic stroke in HIV-infected patients. Neurology 2007;68:1257-1261.

-9 Corral I, Quereda C, Moreno A, Perez-Elias MJ, Dronda F, Casado JL, Muriel A, Masjuan J, Alonso-de-Lecinana M, Moreno S: Cerebrovascular ischemic events in HIV-1-infected patients receiving highly active antiretroviral therapy: incidence and risk factors. Cerebrovasc Dis 2009;27:559-563.

10 Cole JW, Pinto AN, Hebel JR, Buchholz DW, Earley CJ, Johnson CJ, Macko RF, Price TR, Sloan MA, Stern BJ, Wityk RJ, Wozniak MA, Kittner SJ: Acquired immunodeficiency syndrome and the risk of stroke. Stroke 2004;35: 51-56.

11 Qureshi AI, Janssen RS, Karon JM, Weissman JP, Akbar MS, Safdar K, Frankel MR: Human immunodeficiency virus infection and stroke in young patients. Arch Neurol 1997;54:1150-1153.
12 Hoffmann M, Berger JR, Nath A, Rayens M: Cerebrovascular disease in young, HIV-infected, black Africans in the KwaZulu Natal province of South Africa. J Neurovirol 2000; 6:229-236.

13 Patel VB, Sacoor Z, Francis P, Bill PL, Bhigjee AI, Connolly C: Ischemic stroke in young HIV-positive patients in Kwazulu-Natal, South Africa. Neurology 2005;65:759-761.

14 Rabinstein AA: Stroke in HIV-infected patients: a clinical perspective. Cerebrovasc Dis 2003; 15:37-44.

-15 Kossorotoff M, Touzé E, Godon-Hardy S, Serre I, Mateus C, Mas JL, Zuber M: Cerebral vasculopathy with aneurysm formation in HIV-infected young adults. Neurology 2006; 66:1121-1122.

- 16 Jericó C, Knobel H, Calvo N, Sorli ML, Guelar A, Gimeno-Bayon JL, Saballs P, Lopez-Colomes JL, Pedro-Botet J: Subclinical carotid atherosclerosis in HIV-infected patients: role of combination antiretroviral therapy. Stroke 2006;37:812-817.

17 Friis-Møller N, Reiss P, Sabin CA, Weber R, Monforte A, El-Sadr W, Thiébaut R, De Wit S, Kirk O, Fontas E, Law MG, Phillips A, Lundgren JD: Class of antiretroviral drugs and the risk of myocardial infarction. N Engl J Med 2007;356:1723-1735.

18 Elkind MS, Ramakrishnan P, Moon YP, Boden-Albala B, Liu KM, Spitalnik SL, Rundek T, Sacco RL, Paik MC: Infectious burden and risk of stroke: the northern Manhattan study. Arch Neurol 2010;67:33-38.

19 Solages A, Vita JA, Thornton DJ, Murray J, Heeren T, Craven DE, Horsburgh CR Jr: Endothelial function in HIV-infected persons. Clin Infect Dis 2006;42:1325-1332.

20 Jones SC, Radinsky CR, Furlan AJ, Chyatte D, Perez-Trepichio AD: Cortical NOS inhibition raises the lower limit of cerebral blood flow-arterial pressure autoregulation. Am J Physiol 1999;276:H1253-H1262.

21 Schmidt JF, Waldemar G, Vorstrup S, Andersen AR, Gjerris F, Paulson OB: Computerized analysis of cerebral blood flow autoregulation in humans: validation of a method for pharmacologic studies. J Cardiovasc Pharmacol 1990;15:983-988.

22 Dirnagl U, Pulsinelli W: Autoregulation of cerebral blood flow in experimental focal brain ischemia. J Cereb Blood Flow Metab 1990;10:327-336.
23 Schumann P, Touzani O, Young AR, Morello R, Baron JC, MacKenzie ET: Evaluation of the ratio of cerebral blood flow to cerebral blood volume as an index of local cerebral perfusion pressure. Brain 1998;121(Pt 7): 1369-1379.

24 Powers WJ, Grubb RL Jr, Raichle ME: Physiological responses to focal cerebral ischemia in humans. Ann Neurol 1984;16:546-552.

25 Sillesen H, Schroeder T, Steenberg HJ, Hansen HJ: Doppler examination of the periorbital arteries adds valuable hemodynamic information in carotid artery disease. Ultrasound Med Biol 1987;13:177-181.

-26 Derdeyn CP, Carpenter DA, Videen TO, Grubb RL Jr, Powers WJ: Patterns of infarction in hemodynamic failure. Cerebrovasc Dis 2007;24:11-19.

27 Seaberg EC, Benning L, Sharrett AR, Lazar JM, Hodis HN, Mack WJ, Siedner MJ, Phair JP, Kingsley LA, Kaplan RC: Association between human immunodeficiency virus infection and stiffness of the common carotid artery. Stroke 2010;41:2163-2170.

28 Brilla R, Nabavi DG, Schulte-Altedorneburg G, Kemeny V, Reichelt D, Evers S, Schiemann U, Husstedt IW: Cerebral vasculopathy in HIV infection revealed by transcranial Doppler: a pilot study. Stroke 1999;30:811813.

29 Ogasawara K, Ogawa A, Terasaki K, Shimizu $\mathrm{H}$, Tominaga T, Yoshimoto T: Use of cerebrovascular reactivity in patients with symptomatic major cerebral artery occlusion to predict 5-year outcome: comparison of xenon-133 and iodine-123-IMP single-photon emission computed tomography. J Cereb Blood Flow Metab 2002;22:1142-1148.

30 Wang X, Chai H, Yao Q, Chen C: Molecular mechanisms of HIV protease inhibitor-induced endothelial dysfunction. J Acquir Immune Defic Syndr 2007;44:493-499.

- 31 Subsai K, Kanoksri S, Siwaporn C, Helen L, Kanokporn O, Wantana P: Neurological complications in AIDS patients receiving HAART: a 2-year retrospective study. Eur J Neurol 2006;13:233-239.

-32 d'Arminio A, Sabin CA, Phillips AN, Reiss P, Weber R, Kirk O, El-Sadr W, De Wit S, Mateu S, Petoumenos K, Dabis F, Pradier C, Morfeldt L, Lundgren JD, Friis-Moller N: Cardio- and cerebrovascular events in HIV-infected persons. AIDS 2004;18:1811-1817. 
-33 Bozzette SA, Ake CF, Tam HK, Chang SW, Louis TA: Cardiovascular and cerebrovascular events in patients treated for human immunodeficiency virus infection. N Engl J Med 2003;348:702-710.

>34 Lundgren JD, Babiker A, El-Sadr W, Emery S, Grund B, Neaton JD, Neuhaus J, Phillips AN: Inferior clinical outcome of the CD4+ cell count-guided antiretroviral treatment interruption strategy in the SMART study: role of CD4+ cell counts and HIV RNA levels during follow-up. J Infect Dis 2008;197:1145-1155.

\35 Maggi P, Serio G, Epifani G, Fiorentino G, Saracino A, Fico C, Perilli F, Lillo A, Ferraro S, Gargiulo M, Chirianni A, Angarano G, Regina G, Pastore G: Premature lesions of the carotid vessels in HIV-1-infected patients treated with protease inhibitors. AIDS 2000;14:F123-F128.

\36 Goldstein LB, Adams R, Alberts MJ, Appel LJ, Brass LM, Bushnell CD, Culebras A, Degraba TJ, Gorelick PB, Guyton JR, Hart RG, Howard G, Kelly-Hayes M, Nixon JV, Sacco RL: Primary prevention of ischemic stroke: a guideline from the American Heart Association/American Stroke Association Stroke Council: cosponsored by the Atherosclerotic Peripheral Vascular Disease Interdisciplinary Working Group; Cardiovascular Nursing Council; Clinical Cardiology Council; Nutrition, Physical Activity, and Metabolism Council; and the Quality of Care and Outcomes Research Interdisciplinary Working Group: the American Academy of Neurology affirms the value of this guideline. Stroke 2006;37:1583-1633.

- 37 Pearson TA, Blair SN, Daniels SR, Eckel RH, Fair JM, Fortmann SP, Franklin BA, Goldstein LB, Greenland P, Grundy SM, Hong Y, Miller NH, Lauer RM, Ockene IS, Sacco RL, Sallis JF Jr, Smith SC Jr, Stone NJ, Taubert KA: AHA Guidelines for Primary Prevention of Cardiovascular Disease and Stroke: 2002 Update: Consensus Panel Guide to Comprehensive Risk Reduction for Adult Patients Without Coronary or Other Atherosclerotic Vascular Diseases. American Heart Association Science Advisory and Coordinating Committee. Circulation 2002;106:388-391.

-38 National Cholesterol Education Program (NCEP) Expert Panel on Detection, Evaluation, and Treatment of High Blood Cholesterol in Adults (Adult Treatment Panel III): Third Report of the National Cholesterol Education Program (NCEP) Expert Panel on Detection, Evaluation, and Treatment of High Blood Cholesterol in Adults (Adult Treatment Panel III) final report. Circulation 2002;106:3143-3421.

-39 Wilson PW, D’Agostino RB, Levy D, Belanger AM, Silbershatz H, Kannel WB: Prediction of coronary heart disease using risk factor categories. Circulation 1998;97:1837-1847.

$\checkmark 40$ Touzé E, Varenne O, Chatellier G, Peyrard S, Rothwell PM, Mas JL: Risk of myocardial infarction and vascular death after transient ischemic attack and ischemic stroke: a systematic review and meta-analysis. Stroke 2005;36:2748-2755.
41 Dhamoon MS, Elkind MS: Inclusion of stroke as an outcome and risk equivalent in risk scores for primary and secondary prevention of vascular disease. Circulation 2010;121:2071-2078.

42 Dhamoon MS, Moon YP, Paik MC, Sacco RL, Elkind MSV: The inclusion of stroke in risk stratification for primary prevention of vascular events: the Northern Manhattan Study. Stroke 2011;42:2878-2882.

43 Guidelines of the European AIDS Clinical Society, Version 6. Oct 2009. Available at: http://www.europeanaidsclinicalsociety. org/images/stories/EACS-Pdf/eacsguidelines-v6_english.pdf (accessed Jan 5, 2012).

44 Law MG, Friis-Møller N, El-Sadr WM, Weber R, Reiss P, D'Arminio Monforte A, Thiébaut R, Morfeldt L, De Wit S, Pradier C, Calvo G Kirk O, Sabin CA, Phillips AN, Lundgren JD The use of the Framingham equation to predict myocardial infarctions in HIV-infected patients: comparison with observed events in the D:A:D Study. HIV Med 2006;7:218-230.

45 Grinspoon SK, Grunfeld C, Kotler DP, Currier JS, Lundgren JD, Dube MP, Lipshultz SE, Hsue PY, Squires K, Schambelan M, Wilson PW, Yarasheski KE, Hadigan CM, Stein JH, Eckel RH: State of the science conference: initiative to decrease cardiovascular risk and increase quality of care for patients living with HIV/AIDS: executive summary. Circulation 2008;118:198-210.

46 Hammer SM, Eron JJ Jr, Reiss P, Schooley RT, Thompson MA, Walmsley S, Cahn P Fischl MA, Gatell JM, Hirsch MS, Jacobsen DM, Montaner IS, Richman DD, Yeni PG, Volberding PA: Antiretroviral treatment of adult HIV infection: 2008 recommendations of the International AIDS Society-USA panel. JAMA 2008;300:555-570.

47 Lundgren JD, Battegay M, Behrens G, De Wit S, Guaraldi G, Katlama C, Martinez E, Nair D, Powderly WG, Reiss P, Sutinen J, Vigano A: European AIDS Clinical Society (EACS) guidelines on the prevention and management of metabolic diseases in HIV. HIV Med 2008;9:72-81.

48 Sacco RL, Adams R, Albers G, Alberts MJ, Benavente O, Furie K, Goldstein LB, Gorelick P, Halperin J, Harbaugh R, Johnston SC, Katzan I, Kelly-Hayes M, Kenton EJ, Marks M, Schwamm LH, Tomsick T: Guidelines for prevention of stroke in patients with ischemic stroke or transient ischemic attack: a statement for healthcare professionals from the American Heart Association/American Stroke Association Council on Stroke: cosponsored by the Council on Cardiovascular Radiology and Intervention: the American Academy of Neurology affirms the value of this guideline. Circulation 2006;113:e409e449.

49 Savès M, Chêne G, Ducimetière P, Leport C, Le Moal G, Amouyel P, Arveiler D, Ruidavets JB, Reynes J, Bingham A, Raffi F: Risk factors for coronary heart disease in patients treated for human immunodeficiency virus infection compared with the general population. Clin Infect Dis 2003;37:292-298.

\section{0} Stein JH, Hadigan CM, Brown TT, Chadwick E, Feinberg J, Friis-Moller N, Ganesan A, Glesby MJ, Hardy D, Kaplan RC, Kim P, Lo J, Martinez E, Sosman JM: Prevention strategies for cardiovascular disease in HIV-infected patients. Circulation 2008;118:e54e60.

51 Farrugia PM, Lucariello R, Coppola JT: Human immunodeficiency virus and atherosclerosis. Cardiol Rev 2009;17:211-215.

52 El-Sadr WM, Lundgren JD, Neaton JD, Gordin F, Abrams D, Arduino RC, Babiker A, Burman W, Clumeck N, Cohen CJ, Cohn D, Cooper D, Darbyshire J, Emery S, Fatkenheuer G, Gazzard B, Grund B, Hoy J, Klingman K, Losso M, Markowitz N, Neuhaus J, Phillips A, Rappoport C: Strategies for Management of Antiretroviral Therapy(SMART) Study Group. CD4+ count-guided interruption of antiretroviral treatment. N Engl J Med 2006;355:2283-2296.

53 Davis MM, Taubert K, Benin AL, Brown DW, Mensah GA, Baddour LM, Dunbar S, Krumholz HM: Influenza vaccination as secondary prevention for cardiovascular disease: a science advisory from the American Heart Association/American College of Cardiology. Circulation 2006;114:15491553.

54 Calza L, Manfredi R, Colangeli V, Tampellini L, Sebastiani T, Pocaterra D, Chiodo F: Substitution of nevirapine or efavirenz for protease inhibitor versus lipid-lowering therapy for the management of dyslipidaemia. AIDS 2005;19:1051-1058

55 Gazzard BG, Anderson J, Babiker A, Boffito M, Brook G, Brough G, Churchill D, Cromarty B, Das S, Fisher M, Freedman A, Geretti AM, Johnson M, Khoo S, Leen C, Nair D, Peters B, Phillips A, Pillay D, Pozniak A, Walsh J, Wilkins E, Williams I, Williams M, Youle M: British HIV Association Guidelines for the treatment of HIV-1-infected adults with antiretroviral therapy 2008. HIV Med 2008; 9:563-608

56 Sabin CA, Worm SW, Weber R, Reiss P, ElSadr W, Dabis F, De Wit S, Law M, D’Arminio Monforte A, Friis-Moller N, Kirk O, Pradier C, Weller I, Phillips AN, Lundgren JD: Use of nucleoside reverse transcriptase inhibitors and risk of myocardial infarction in HIV-infected patients enrolled in the D:A:D study: a multi-cohort collaboration. Lancet 2008;371:1417-1426.

57 Falutz J, Allas S, Blot K, Potvin D, Kotler D, Somero M, Berger D, Brown S, Richmond G, Fessel J, Turner R, Grinspoon S: Metabolic effects of a growth hormone-releasing factor in patients with HIV. N Engl J Med 2007;357: 2359-2370.

58 Bozzette SA, Ake CF, Tam HK, Phippard A, Cohen D, Scharfstein DO, Louis TA: Longterm survival and serious cardiovascular events in HIV-infected patients treated with highly active antiretroviral therapy. J Acquir Immune Defic Syndr 2008;47:338-341. 